\title{
Embryo Transfer in Subfertile Mares
}

\author{
By T. Katila, M. Oijala, T. Kotilainen and K. Väisänen \\ Department of Veterinary Clinical Medicine, \\ College of Veterinary Medicine, Hautjärvi, Finland.
}

\begin{abstract}
Katila, T., M. Oijala, T. Kotilainen and K. Väisänen: Embryo transfer in subfertile mares. Acta vet. scand. 1989, 30, 329-333. - Four subfertile mares (at least 2 barren years) were used as donors in an embryo transfer program. The embryo recovery rate was $50 \%$, varying between $0-100$. The transfer of 9 embryos resulted in the pregnancy rate of $44 \%$. The efficiency of embryo transfer using subfertile mares is low. In this material $20 \%$ of flushings resulted in a pregnancy.
\end{abstract}

barren mare; embryo recovery rate.

\section{Introduction}

Embryo transfer can increase the number of progeny from valuable females. Old, infertile mares, which are unable to carry a pregnancy to term can give birth to a viable foal by means of embryo transfer. It also enables 2 year-old mares and racing mares to get offsprings at an early age. However, this potentially valuable technique has had an unfavourable reception among many breed registration authorities.

By repeated embryo recovery attempts it is possible to obtain as many as 6-8 embryos from a normal, healthy mare during a breeding season, with the possibility of 3-4 foals (Imel et al. 1981). Embryo recovery rate from mares with reproductive problems is about half of that from normal mares (Table 1). Fertilization failures, embryonic defects, abnormal oviduct transport or unfavourable oviducal or uterine environment prior to day 7 are postulated as potential causes of embryonic loss in barren mares. Ball et al. (1986) showed that fertilization rates were similar for normal and subfertile mares and day 2 embryos collected from barren mares were morphologically normal. However, embryos collected seven days postovulation from subfertile mares had more morphological abnormalities than embryos from maiden mares (Woods et al. 1985, Schlafer et al. 1987). The discovery of Ball et al. (1986) that conception rates of normal and barren mares were similar 2 days after ovulation $(71 \%$ vs $79 \%$ ) but differed significantly 14 days after ovulation ( $80 \%$ vs $20 \%)$ and the fact that embryo recovery rates 7-8 days after ovulation are low in subfertile mares (Table 1), indicate that the oviductal or early uterine environment kills the embryo. When normal embryos were transferred to normal or subfertile mares 7-8 days after ovulation, the embryonic survival rate was the same in both groups, which shows that the uterine environment from 7 days onwards was adequate to support the embryo (Ball \& Woods 1986). When day 4 embryos were transferred from normal and subfertile mares to normal recipients, the pregnancy rates were $52 \%$ vs $23 \%$ (Ball \& Woods 1986), which suggests that the oviductal environment had damaged the embryo in subfertile mares.

The success of non-surgical transfer of equine embryos has increased over the last few years, and there does not seem to be a difference in the survival rate for embryos flus- 
Table 1. Embroy recovery rates from normal and subfertile mares.

\begin{tabular}{|c|c|c|c|c|}
\hline \multirow{3}{*}{$\frac{\text { Reference }}{\text { Douglas } 1982}$} & \multicolumn{4}{|c|}{$\begin{array}{c}\text { Recovery rate } \\
\text { Embryos found/recovery attempts }\end{array}$} \\
\hline & \multicolumn{2}{|c|}{ Normal mares \% } & \multicolumn{2}{|c|}{ Subfertile mares $\%$} \\
\hline & $56 / 100$ & 56 & $12 / 35$ & 34 \\
\hline Squires et al. 1982 & $128 / 160$ & 80 & $10 / 36$ & 28 \\
\hline Douglas et al. 1985 & - & & $41 / 146$ & 28 \\
\hline Pascoe et al. 1985 & $50 / 98$ & 51 & $5 / 15$ & 33 \\
\hline Squires \& Garcia 1985 & & 85 & $24 / 109$ & 22 \\
\hline Woods et al. 1985 & $29 / 42$ & 69 & $17 / 42$ & 49 \\
\hline$\overline{\mathrm{x}}=$ & $263 / 400$ & 66 & $119 / 383$ & 31 \\
\hline
\end{tabular}

hed from normal or subfertile donors 6-8 days after ovulation. Pregnancy rates of $45 \%$ (Juliano et al. 1985) and 67\% (Squires et al. 1985) have been reported for normal mares and $50-54 \%$ for subfertile donors (Douglas 1982, Douglas et al. 1985).

This paper presents the results of collection and non-surgical transfer of embroyos from 4 barren mares.

\section{Material and methods}

\section{Donor mares}

A total of 4 commercial broodmares with a history of reproductive failure for at least 2 consecutive years were used as donors during the breeding seasons of 1986 and 1987 at the Hautjärvi Clinics of the College of Veterinary Medicine (Table 2). Prior to the embryo transfer program the donors were given a thorough gynaecological examination including a uterine biopsy and swab and a chromosome analysis for donors 1 and 2 .

Donor 1. The 15 year-old Finnhorse mare had been barren for 8 years after her first foal. Once she had been pregnant at day 30 postovulation but experienced later an embryonic loss. Endometrial biopsy revealed a chronic degenerative endometritis and the endometrium was classified as grade III according to Kenney (1978). A chromosomal polymorphism of constitutive heterochromatin was found in autosome 1 .

Donor 2. The 9 year-old nulliparous Standardbred mare had been barren for 5 years with a history of early embryonic loss during 4 years. She had a chronic infiltrative and degenerative endometritis (grade III). Her karyotype was normal.

Table 2. Recovery and transfer of embryos from 4 barren mares.

\begin{tabular}{|c|c|c|c|c|c|c|}
\hline Donor & $\begin{array}{c}\text { Age } \\
\text { (years) }\end{array}$ & $\begin{array}{r}\text { Years } \\
\text { barren }\end{array}$ & $\begin{array}{c}\text { Endometrial } \\
\text { biopsy } \\
\text { classification }\end{array}$ & $\begin{array}{c}\text { Embryos } \\
\text { recovered/ } \\
\text { attempts }(\%)\end{array}$ & $\begin{array}{c}\text { Pregnancies/ } \\
\text { transferred } \\
\text { Day } 7 \text { embryos }\end{array}$ & $\begin{array}{c}\text { Pregnancies/ } \\
\text { flushings }\end{array}$ \\
\hline I & 15 & 8 & III & $1 / 4 \quad(25)$ & $1 / 1$ & $1 / 4$ \\
\hline 2 & 9 & 5 & III & $0 / 5 \quad(0)$ & $0 / 0$ & $0 / 5$ \\
\hline 3 & 11 & 3 & II & $7 / 6^{* *}(100)$ & $3 / 6$ & $3 / 6$ \\
\hline 4 & 9 & 2 & I & $2 / 5 \quad(40)$ & $0 / 2$ & $0 / 5$ \\
\hline$\overline{\mathrm{x}}=$ & 11 & 4,5 & & $2,5 / 5$ & $1 / 2,25(44 \%)$ & $1 / 5(20 \%)$ \\
\hline
\end{tabular}

** Two embryos from 1 flushing, 7 and 10 day old. 
Donor 3. The 11 year-old Standardbred mare had had 3 foals and 3 barren years with early pregnancy loss. She had a chronic infiltrative and degenerative endometritis (grade II).

Donor 4. The 9 year-old nulliparous Standardbred mare had experienced 2 years of reproductive failure. She had aborted an 8 month old fetus 3 months before the first embryo recovery attempt. Her endometrium, however, appeared to be normal (biopsy grade I).

\section{Recipient mares}

Five 3 year-old maiden Finnhorse mares with grade I endometrial biopsies were available as recipients for donor mare 1 . Three Standardbred mares, 5-9 years of age, were reserved for donor mare 2. The Standardbred mares had grade I or I-II endometrial biopsies.

Eight Standardbred mares, 4-13 years of age, were used as recipients for donor mares 3 and 4 . They were normal, cycling mares with no previous history of infertility.

\section{Estrus synchronization, examination and in- semination}

Estrus was synchronized with $0,25 \mathrm{mg}$ chloprostenol (Estrumate; ICI) during the luteal phase. Immediately after flushing, the donor mares were given prostaglandin to minimize the interval between embryo collections. Remaining recipients were given prostaglandin 1 or 2 days later.

Daily teasing, rectal palpation, ultrasonography and progesterone determination were used as aids in estrus and ovulation control and in pregnancy examinations.

Standardbred mares (donors 2, 3 and 4) were inseminated with cooled semen, which had been transported $200 \mathrm{~km}$ in an Equitainer container (Hamilton Equine Systems). Extended but not cooled semen was brought to the Finnhorse mare (donor 1) immediately after semen collection from a nearby studfarm $(20 \mathrm{~km})$. The insemination dose was always in excess of 500 million progressively motile spermatozoa and the stallions were of proven fertility.

\section{Embryo recovery and transfer}

Embryo recovery attempts and transfers were performed during June-September, 7 days after ovulation. Modified Dulbecco's phosphate-buffered saline (PBS) with $0,4 \%$ bovine serum albumin or $1 \%$ fetal calf serum (FCS) was infused into the uterus by gravity flow through a flexible two-way flushing catheter (Gibbons Balloon Catheter; Franklin Medical).

In 19861,51 of flushing medium was infused into the uterus 2 times and the outflow of the fluid was assisted by massage of the uterus per rectum if necessary. In 1987 flushing medium was infused into the uterus until the lumen was distended $(2,5-3,51)$ and the mare started to show signs of discomfort. While massaging the fluid-filled uterus, the medium was allowed to flow out into collection cylinders. The procedure was not repeated. When the embryo was located, it was washed 3 times in PBS with $20 \%$ FCS.

The embryo was loaded between fluid and air columns into a $0,25 \mathrm{ml}$ straw, which was placed into a Cassou bovine inseminating gun and deposited into the body of the uterus. The recipient was given prostaglandin inhibitor - $500 \mathrm{mg}$ flunixin meglumin (Finadyne; Orion) iv. - before the transfer.

\section{Results}

Embryo recovery

The mean interval between consecutive embryo recovery attempts was $16,4 \pm 3,0$ days. An average of $97 \%$ of fluid infused into the uterus was recovered. Embryo recovery rate varied considerably among mares (Table 2). 
Embryos were found in 1 of 9 attempts $(11 \%)$ in 1986 (donors 1 and 2) and in 8 of 11 attempts (73\%) in 1987 (donors 3 and 4). Thus, a total of 20 embryo recovery attempts yielded embryos on 9 occasions giving an overall recovery rate of $45 \%$. On 1 occasion 2 embryos were found; besides one day 7, a day 10 embryo, $2,8 \mathrm{~mm}$ in diameter, was collected as a result of asynchronous ovulations. No embryos were recovered from donor mare 2. A starch grain test ( $\mathrm{Al}$ len et al. 1979) proved that the oviducts were patent. On the other hand, the recovery rate from donor mare 3 was $100 \%$.

\section{Pregnancy results}

Transfer of 9 day 7 embryos resulted in four pregnancies (44\%) (Table 2). All embryos were transferred to recipients that had ovulated 1 day prior to the donor or within 3 days after the donor. The recipient of donor mare 1 produced a live foal in 1987 and the 3 foals from donor mare 3 were born in summer 1988.

\section{Discussion}

The overall results are comparable with those published earlier on subfertile mares. However, the mares or, in fact, the years differed considerably from each other. In 1986 the embryo recovery rate from subfertile mares was extremely low, but so were the results of normal research mares flushed 6 days after ovulation in another project in the same clinic. In 1987 the recovery percent in the latter project was 67 . The major difference between these years in flushing technique was in the massaging of the uterus during fluid recovery. In 1986 uterus was massaged only, if all the fluid was not recovered, whereas in 1987 massage of the uterus was started when half of the infused fluid had been siphoned ut.

Possible failure in flushing technique makes it difficult to evaluate embryo collection results of donors 1 and 2. Pascoe et al. (1985) reported that the combined effect of endometrial pathology and prolonged infertility (barren 2 years) reduced embryo recovery rate to only $15 \%$. The reproductive status of donor mares 1 and 2 was similar. Surprisingly enough, donor mare 2 conceived at the beginning of the next breeding season and gave birth to a live foal. Donor mare 1 conceived in September after the embryo recovery attempts but lost the conseptus between 18 and 23 days. The importance of heterochromatin polymorphism found in this mare is obscure. Two out of 12 aborted equine fetuses exhibited a large polymorphism in the amount of heterochromatin in autosome 1 , whereas none of the examined 45 normal individuals showed large heterochromatic polymorphism (Haynes \& Reisner 1982). Futher research is needed to show the effect of heterochromatic polymorphism on fertility. Donor mare 3 was very encouraging. Despite her reproductive history, the results are comparable to those of normal mares. She conceived next year and delivered a live foal. Several embryo flushings did not have any adverse effect on the subsequent reproduction of the mares, on the contrary, most of them performed better than they had done previously.

Donor 4 had the least number of barren years and the best endometrium. She may have had endocrinological disturbances. She was very difficult to bring in estrus at the beginning of the program and next year the same problem continued. By the middle of June she had not been bred yet, because estrus had not been observed. However, she conceived in late summer and produced a foal next year.

According to Douglas et al. (1985) the efficiency of producing a pregnancy per cycle using subfertile mares as donors is $15 \%$. In 
our study it was $20 \%$. Embryo transfer from subfertile mares is a rather unefficient technique. However, the mares selected for donors are quite valuable broodmares and their foals highly priced, which make it justified to use expensive methods. The causes of infertility are wide and varied and that is why it is difficult to predict the outcome of embryo transfer in individual mares.

Research conducted by Ball et al. (1986) suggests that flushing of the uterus (6-8 days postovulation) is too late. Most embryos have already died in the hostile oviducal environment which results in low recovery rates. Embryos should be collected shortly after fertilization from the uterine tube. In vitro fertilization would offer another possibility. It remains to be seen if these techniques will be developed in the future to provide new aspects for the treatment of problem mares.

\section{Acknowledgements}

The authors thank the Laukko Studfarm and the State Horse Breeding Institute for providing the mares.

\section{References}

Allen WE, Kessy BM, Noakes DE: Evaluation of uterine tube function in pony mares. Vet. Rec. 1979, 105, 364-366.

Ball BA, Little TV, Hillman GL, Woods GL: Pregnancy rates at Days 2 and 14 and estimated embryonic loss rates prior to Day 14 in normal and subfertile mares. Theriogenology 1986, 26, 611619.

Ball BA, Woods GL: Pregnancy wastage in mares. Proc. of the Ann. Meet. of Soc. for Theriog., N.Y. 1986, 120-125.

Douglas RH: Some aspects of equine embryo transfer. J. Reprod. Fert. 1982. Suppl. 32, 405-408.

Douglas RH, Burns PJ, Hershman L: Physiological and commercial parameters for producing progeny from subfertile mares by embryo transfer. Equine vet. J. 1985, Suppl. 3, 111-114.
Haynes SE, Reisner AH: Cytogenetic and DNA analyses of equine abortion. Cytogenet. Cell Genet. 1982, 34, 204-214.

Imel KJ, Squires EL, Elsden RP, Shideler RK: Collection and transfer of equine embryos. J. Amer. vet. med. Assoc. 1981, 179, 987-991.

Juliano MF, Squires EL, Cook VM: Effect of age of equine embryos and method of transfer on pregnancy rate. J. Anim. Sci. 1985, 60, 258-263.

Kenney RM: Cyclic and pathologic changes of the mare endometrium as detected by biopsy, with a note on early embryonic death. J. Amer. vet. med. Assoc. 1978, 172, 241-262.

Pascoe DR, Liu IKM, Spensley MS, Hughes JP: Effect of endometrial pathology on the success of non-surgical embryo transfer. Equine vet. J. 1985. Suppl. 3, 108-110.

Schlafer DH, Dougherty EP, Woods GL: Light and ultrastructural studies of morphological alterations in embryos collected from maiden and barren mares. J. Reprod. Fert., 1987. Suppl. 35, 695.

Squires $E L$, Imel $K J$, Iuliano $M F$, Shideler $R K$ : Factors affecting reproductive efficiency in an equine embryo transfer programme. J. Reprod. Fert., 1982. Suppl. 32, 409-414.

Squires EL, Garcia RH, Ginther OJ: Factors affecting success of equine embryo transfer. Equine vet. J. 1985. Suppl. 3, 92-95.

Woods GL, Baker CB, Hillman RB, Schlafer DH: Recent studies relating to early embryonic death in the mare. Equine vet. J. 1985. Suppl. 3, 104107.

\section{Sammandrag}

Transfer av embryo hos subfertila ston.

Fyra subfertila ston (gatt galla i minst 2 år) användes som donatorer i ett program för embryotransfer. Femtio procent av embryon tillvaratogs (varians 0$100 \%$ ). Transfer av 9 embryon gav en dräktighetsresultat på $\mathbf{4 4 \%}$. Embryotransfer från subfertila ston leder till nedsatt effektivitet. I föreliggande material resulterade $20 \%$ av sköljningarna i dräktighet.

(Accepted August 30, 1988).

Reprints may be requested from: Terttu Katila, College of Veterinary Medicine, SF-04840 Hautjärvi, Finland. 
